\title{
Ethanol extract of Cnidium officinale exhibits anti-inflammatory effects in BV2 microglial cells by suppressing NF-kB nuclear translocation and the activation of the PI3K/Akt signaling pathway
}

\author{
SHIN HWA LEE ${ }^{1 *}, J_{U N}$ HYUK LEE ${ }^{2 *}$, EUN YOUNG OH ${ }^{3}$, GI-YOUNG KIM ${ }^{4}$, \\ BYUNG TAE $\mathrm{CHOI}^{3}$, $\mathrm{CHEOLMIN} \mathrm{KIM}^{5,6}$ and YUNG HYUN CHOI ${ }^{7,8}$
}

\begin{abstract}
${ }^{1}$ Department of Biological Sciences, Korea Advanced Institute of Science and Technology, Daejeon 305-701;
${ }^{2}$ Biotechnology Examination Division, Chemistry and Biotechnology Examination Bureau, Korean Intellectual Property Office, Daejeon 302-701; ${ }^{3}$ Division of Meridian and Structural Medicine, School of Korean Medicine,

Busan National University, Yangsan 626-870; ${ }^{4}$ Laboratory of Immunobiology, Department of Marine Life Sciences, Jeju National University, Jeju 690-756; ${ }^{5}$ Research Center for Anti-Aging Technology Development, Busan National University,

Busan 609-735; ${ }^{6}$ Department of Biochemistry, Busan National University College of Medicine, Yangsan 626-870;

${ }^{7}$ Department of Biochemistry, Dongeui University College of Oriental Medicine, Busan 614-052;

${ }^{8}$ Anti-Aging Research Center and Blue-Bio Industry RIC, Dongeui University, Busan 614-714, Republic of Korea
\end{abstract}

Received March 19, 2013; Accepted July 9, 2013

DOI: $10.3892 /$ ijmm.2013.1447

\begin{abstract}
Chronic microglial activation endangers neuronal survival through the release of various toxic pro-inflammatory molecules; thus, negative regulators of microglial activation have been identified as potential therapeutic candidates for several neurological diseases. In this study, we investigated the inhibitory effects of an ethanol extract of Cnidium officinale rhizomes (EECO), which has been used as a herbal drug in Oriental medicine, on the production of lipopolysaccharide (LPS)-induced pro-inflammatory mediators, such as nitric oxide (NO) and prostaglandin $\mathrm{E}_{2}\left(\mathrm{PGE}_{2}\right)$, as well as that of pro-inflammatory cytokines in BV2 microglia cells. EECO significantly inhibited the excess production of $\mathrm{NO}$ and $\mathrm{PGE}_{2}$ in LPS-stimulated BV2 microglia cells. It also attenuated the expression of inducible NO synthase, cyclooxygenase-2, as well as that of pro-inflammatory cytokines, such as interleukin-1 $\beta$ and tumor necrosis factor- $\alpha$. Moreover, EECO exhibited antiinflammatory properties by suppressing nuclear factor $-\kappa B$ (NF- $\mathrm{kB}$ ) translocation and the activation of the phosphoinositide 3-kinase/Akt pathway in LPS-stimulated BV2 cells. These
\end{abstract}

Correspondence to: Dr Yung Hyun Choi, Department of Biochemistry, Dongeui University College of Oriental Medicine, San 45, Yangjung-dong, Busanjin-gu, Busan 614-052, Republic of Korea E-mail: choiyh@deu.ac.kr

${ }^{*}$ Contributed equally

Key words: Cnidium officinale Makino, microglia, anti-inflammation, nuclear factor- $\mathrm{\kappa B}$, phosphoinositide 3-kinase/Akt results indicate that EECO exerts anti-inflammatory effects in LPS-stimulated BV2 microglial cells by inhibiting proinflammatory mediators and cytokine production by blocking the NF- $\mathrm{BB}$ pathway. These findings suggest that EECO has substantial therapeutic potential for the treatment of neurodegenerative diseases accompanied by microglial activation.

\section{Introduction}

Microglia are important cells that are involved in initial responses to tissue damage in the central nervous system (CNS). However, abnormally overactivated microglia promote the expression of pro-inflammatory mediators, such as nitric oxide (NO) and prostaglandin $\mathrm{E}_{2}\left(\mathrm{PGE}_{2}\right)$, as well as that of pro-inflammatory cytokines, including interleukin-1 $\beta$ (IL-1 $\beta$ ), tumor necrosis factor- $\alpha$ (TNF- $\alpha$ ) and monocyte chemoattractant protein-1 and other factors that contribute to the development of chronic inflammatory diseases (1-3). In particular, microglia are activated by lipopolysaccharides (LPS), $\beta$-amyloid, thrombin, or interferon- $\gamma$, and the secretion of inflammatory molecules by abnormally activated microglia disturbs the homeostasis of the immune system, thus inducing and promoting degenerative CNS autoimmune diseases, such as multiple sclerosis, Alzheimer's disease and Parkinsonism (4-6). Therefore, understanding congenital immune system disorders related to the overactivation of microglia and controlling the inflammation molecules secreted by abnormally activated microglia is an approach to delaying chronic inflammatory diseases.

The transcription factor, nuclear factor- $\mathrm{\kappa B}$ (NF- $\mathrm{\kappa B}$ ), plays a central role in the regulation of several genes responsible for the generation of pro-inflammatory mediators and cytokines. In normal cells, NF-kB subunits are present in the cytosol bound 
to the inhibitory protein $\mathrm{I} \kappa \mathrm{B}(\mathrm{I} \kappa \mathrm{B})$, which inactivates them $(7,8)$. However, in response to various stimuli, such as LPS, IкB is rapidly degraded by the ubiquitin-proteasome pathway. The degradation of $\mathrm{I} \kappa \mathrm{B}$ induces the translocation of $\mathrm{NF}-\kappa \mathrm{B}$ subunits into the nucleus, and the $\mathrm{NF}-\kappa \mathrm{B}$ subunits bind to the promoter regions of target genes, including inducible NO synthase (iNOS), cyclooxygenase-2 (COX-2), TNF- $\alpha$ and IL-1 $\beta$, and stimulate their transcription. The activation of the phosphoinositide 3-kinase (PI3K)/Akt signaling pathway plays an important role in regulating LPS-induced pro-inflammatory responses by inducing $\mathrm{NF}-\kappa \mathrm{B}$ activation through proteasome-dependent $\mathrm{I} \kappa \mathrm{B}$ degradation (9-14). Therefore, inhibiting NF- $\kappa \mathrm{B}$ activation through the PI3K/Akt pathway results in anti-inflammatory effects.

Cnidium officinale (C. officinale) Makino, which belongs to the Umbelliferae family, is a perennial herb native to China. The dried rhizomes of $C$. officinale have been used as one of the most commonly prescribed traditional Oriental medicinal herbs in East Asian countries. In Korean traditional medicine, they are widely used in the treatment of menstrual disturbances and as a blood pressure depressant, as well as for relieving pain from headaches and rheumatic arthralgia (15-20). Although some pharmacological beneficial effects of this herb and extracts of its rhizome have recently been reported, including anticancer, anti-inflammatory and antioxidant effects (21-24), its molecular mechanisms of action have not yet been fully elucidated. Therefore, the present study was conducted to evaluate the effects of an ethanol extract of $C$. officinale rhizomes (EECO) on the production of pro-inflammatory mediators and cytokines and the respective regulatory genes with a focus on the underlying molecular mechanisms in LPS-stimulated BV2 microglial cells.

\section{Materials and methods}

Reagents, chemicals and preparation of EECO. LPS and 3-(4,5-dimethylthiazol-2-yl)-2,5-diphenyl-tetrazolium bromide (MTT) were purchased from Sigma-Aldrich (St. Louis, MO, USA). Antibodies against COX-2, iNOS, TNF- $\alpha$, IL- $1 \beta, N F-\kappa B$ p65 and I $\kappa$ B- $\alpha$ were purchased from Santa Cruz Biotechnology, Inc. (Santa Cruz, CA, USA). Antibodies against phosphorylated PI3K (p-PI3K), PI3K, phosphorylated Akt (p-Akt) and Akt were obtained from Cell Signaling Technology (Beverly, MA, USA). Antibodies against nucleolin and actin were obtained from Sigma-Aldrich. Peroxidase-labeled goat anti-rabbit immunoglobulin was purchased from Koma Biotechnology (Seoul, Korea). Other chemicals were purchased from Sigma-Aldrich. To prepare EECO, the rhizomes of $C$. officinale, which were obtained from Dongeui University Oriental Hospital (Busan, Korea), were pulverized and extracted twice with 10 volumes of $80 \%$ ethanol at $85-90^{\circ} \mathrm{C}$ in a reflux condenser for $3 \mathrm{~h}$, and then filtered with a $50 \mu \mathrm{m}$ filter and concentrated by vacuum evaporation at $60^{\circ} \mathrm{C}$. The solid form of the extract was dissolved in dimethyl sulfoxide.

Cell culture and viability assay. BV2 microglial cells were cultured at $37^{\circ} \mathrm{C}$ in $5 \% \mathrm{CO}_{2}$ in Dulbecco's modified Eagle's medium (DMEM) supplemented with $5 \%$ fetal bovine serum and antibiotics (WelGENE Inc., Daegu, Korea). In all the experiments, the cells were pre-treated with the indicated concentrations of EECO for $1 \mathrm{~h}$ prior to the addition of LPS $(500 \mathrm{ng} / \mathrm{ml})$ in serum-free DMEM. Cell viability was measured based on the formation of blue formazan that was metabolized from colorless MTT by mitochondrial dehydrogenases, which are active only in live cells. In brief, the BV2 cells were seeded and treated with reagents for the indicated periods of time. Following treatment, the medium was removed, and the cells were incubated with $0.5 \mathrm{mg} / \mathrm{ml}$ of MTT solution for $2 \mathrm{~h}$ at $37^{\circ} \mathrm{C}$ and $5 \% \mathrm{CO}_{2}$, and then the supernatant was removed and the formation of formazan was measured at $540 \mathrm{~nm}$ using a microplate reader (Dynatech MR-7000; Dynatech Laboratories, Chantilly, VA, USA).

Measurement of NO. The concentration of NO generated by BV2 cells activated by LPS was detected using Griess reagent [1\% sulfanilamide in $5 \%$ phosphoric acid and $0.1 \% \mathrm{~N}-(1-$ naphthyl)ethylenediamine dihydrochloride]. BV2 cells were cultured for $24 \mathrm{~h}$ in a 6 -well culture plate, pre-treated with various concentrations of EECO for $1 \mathrm{~h}$, and then treated again with LPS $(500 \mathrm{ng} / \mathrm{ml})$. After $24 \mathrm{~h}$ of culture, the cell culture medium was collected and the same quantity of Griess reagent was added to induce a reaction at room temperature. The optical density of the reaction solution was measured at $540 \mathrm{~nm}$ using a microplate reader and the quantity of $\mathrm{NO}$ generated by the cells was calculated based on the concentration of the sodium nitrite $\left(\mathrm{NaNO}_{2}\right)$ standard solution (standard curve).

Measurement of $P G E_{2}$. To measure the quantity of $\mathrm{PGE}_{2}$ generated by BV2 cells, medium from the cultures under the same conditions was collected and the quantity of $\mathrm{PGE}_{2}$ generated was measured using a $\mathrm{PGE}_{2}$ enzyme-linked immunosorbent assay (ELISA) kit (Cayman Chemical Co., Ann Arbor, MI, USA). The concentration $(\mathrm{pg} / \mathrm{ml})$ of $\mathrm{PGE}_{2}$ in the cell culture medium was calculated based on the concentrations of the standard solution as previously described (25).

Measurement of cytokines. The levels of IL-1 $\beta$ and TNF- $\alpha$ were measured using ELISA kits (R\&D Systems, Minneapolis, MN, USA) according to the manufacturer's instructions. Briefly, BV2 cells were loaded in 24-well plates and pre-treated with the indicated EECO concentrations for $1 \mathrm{~h}$ prior to stimulation with $500 \mathrm{ng} / \mathrm{ml}$ LPS for $24 \mathrm{~h}$. A total of $100 \mu \mathrm{l}$ of culture medium supernatant was collected to determine IL-1 $\beta$ and TNF- $\alpha$ concentration by ELISA.

Isolation of total RNA and reverse transcription-polymerase chain reaction ( $R T-P C R)$. RT-PCR was conducted to examine the effects of EECO on the expression of LPS-induced iNOS, COX-2, and inflammatory cytokines at the transcription level. Total RNA was separated from the BV2 cells using TRIzol reagent (Invitrogen, Carlsbad, CA, USA) according to the manufacturer's instructions and reverse-transcribed using MMLV reverse transcriptase (Promega, Madison, WI, USA) to produce cDNA. The cDNA was amplified by PCR using specific primers: iNOS forward, 5'-CCT CCT CCA CCC TAC CAA GT-3' and reverse, 5'-CAC CCA AAG TGC TTC AGT CA-3'; COX-2 forward, 5'-AAG ACT TGC CAG GCT GAA CT-3' and reverse, 5'-CTT CTG CAG TCC AGG TTC AA-3'; IL-1 $\beta$ forward, 5'-ATG GCA ACT GTT CCT GAA CTC AAC T-3' and reverse, 5'-TTT CCT TTC TTA GAT ATG GAC AGG AC-3'; TNF- $\alpha$ forward, 5'-GCG ACG TGG AAC TGG CAG AA-3' and reverse, 5'-TCC ATG CCG TTG GCC AGG AG-3'; 
and GAPDH forward, 5'-ACC ACA GTC CAT GCC ATC AC-3' and reverse, 5'-TCC ACC ACC CTG TTG CTG TA-3'. The following PCR conditions were applied: iNOS, COX-2, IL-1 $\beta$ and TNF- $\alpha$ : 25 cycles of denaturation at $94^{\circ} \mathrm{C}$ for $30 \mathrm{sec}$, annealing at $59^{\circ} \mathrm{C}$ for $30 \mathrm{sec}$, and extension at $72^{\circ} \mathrm{C}$ for $30 \mathrm{sec}$; GAPDH, 23 cycles of denaturation at $94^{\circ} \mathrm{C}$ for $30 \mathrm{sec}$, annealing at $57^{\circ} \mathrm{C}$ for $30 \mathrm{sec}$ and extension at $72^{\circ} \mathrm{C}$ for $30 \mathrm{sec}$. The PCR products were electrophoresed on $1.5 \%$ agarose gels and stained with ethidium bromide. GAPDH was used as an internal control to evaluate relative expression.

Protein extraction and western blot analysis. The cells were washed three times with phosphate-buffered saline (PBS) and lysed in lysis buffer [1\% Triton X-100, $1 \%$ deoxycholate, $0.1 \%$ sodium azide $\left(\mathrm{NaN}_{3}\right)$ ] containing protease inhibitor cocktail tablets to isolate total protein (Roche Diagnostics $\mathrm{GmbH}$, Mannheim, Germany). In a parallel experiment, cytoplasmic and nuclear extracts were prepared using NE-PER nuclear and cytosolic extraction reagents (Pierce, Rockford, IL, USA) according to the manufacturer's instructions. The protein concentrations were determined using a Bio-Rad protein assay kit (Bio-Rad, Hercules, CA, USA). Equal amounts of protein were separated on SDS-polyacrylamide gels and transferred onto nitrocellulose membranes (Schleicher \& Schuell, Inc., Keene, NH, USA) by electroblotting. Proteins were detected using an enhanced chemiluminescence detection system (Pierce).

Immunofluorescence. The prepared cells were washed twice with PBS and fixed for $15 \mathrm{~min}$ at $4^{\circ} \mathrm{C}$ using $4 \%$ paraformaldehyde. The cells were washed again with PBS, reactions were induced for 20 min at $4^{\circ} \mathrm{C}$ in PBS that contained $0.3 \%$ Triton X-100, and then reactions were induced for $1 \mathrm{~h}$ at room temperature in PBS containing $2 \%$ bovine serum albumin (BSA) to suppress non-specific reactions. The anti-NF- $\kappa$ B p65 antibody was then diluted to 1:200 in a PBS solution that contained 2\% BSA to induce reactions for $2 \mathrm{~h}$ at room temperature. The cells were washed three times in PBS and fluorescein isothiocyanate (FITC)-conjugated IgG (Molecular Probes, Eugene, OR, USA), which is a secondary antibody, was diluted to 1:100 to induce reactions for $1 \mathrm{~h}$ at room temperature. Samples of the immunofluorescence-stained cells were observed under a confocal laser scanning microscope (Olympus, Tokyo, Japan). A wavelength of $488 \mathrm{~nm}$ was used for FITC, and the images were reassembled into final three-dimensional images according to the manufacturer's instructions (Olympus Fluoview 300, Olympus).

Statistical analysis. All results are expressed as the means \pm standard errors. Each experiment was repeated at least three times. Statistical significances were identified between each treated group by the paired Student's t-test. A P-value $<0.05$ was considered to indicate a statistically significant difference.

\section{Results}

Inhibition of LPS-induced $N O$ and $P G E_{2}$ production by EECO. To determine the inhibitory effects of EECO on LPS-induced $\mathrm{NO}$ and $\mathrm{PGE}_{2}$ production, $\mathrm{BV} 2$ macroglial cells were incubated with the indicated concentrations of EECO in the presence or absence of LPS for $24 \mathrm{~h}$, and the levels of $\mathrm{NO}$ and $\mathrm{PGE}_{2}$ production were measured in the culture medium using Griess reagent
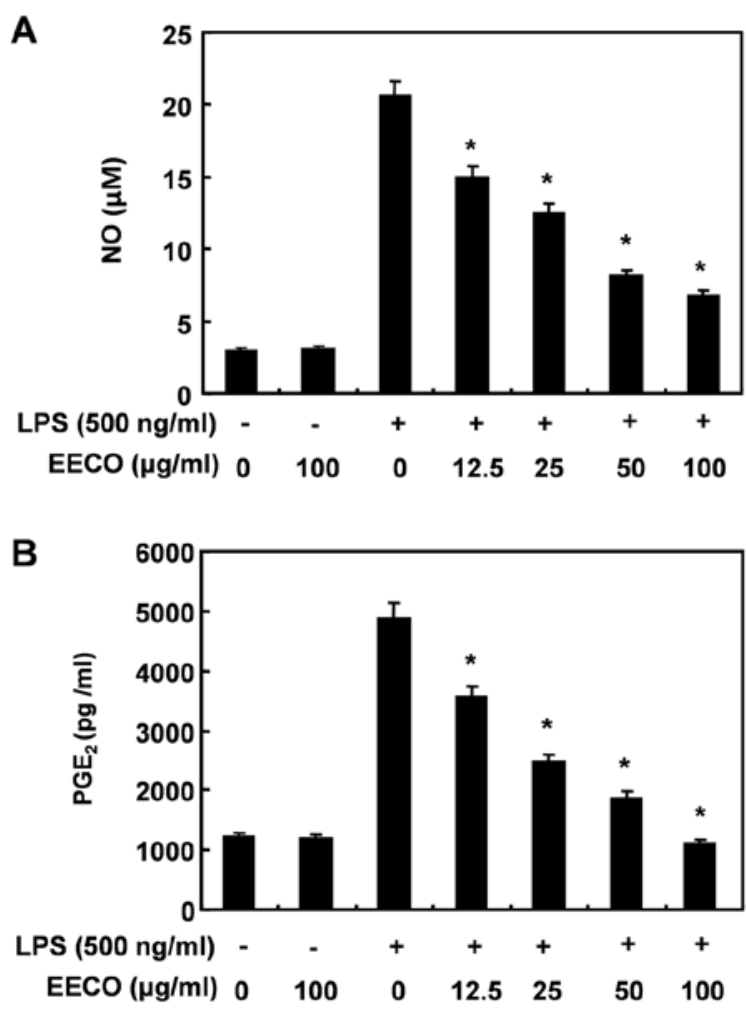

Figure 1. Inhibition of nitric oxide $(\mathrm{NO})$ and prostaglandin $\mathrm{E}_{2}\left(\mathrm{PGE}_{2}\right)$ production by the ethanol extract of Cnidium officinale rhizomes (EECO) in lipopolysaccharide (LPS)-stimulated BV2 microglia cells. BV2 cells were pretreated with various concentrations of EECO $(12.5-100 \mu \mathrm{g} / \mathrm{ml})$ for $1 \mathrm{~h}$ prior to incubation with LPS (500 ng/ml) for $24 \mathrm{~h}$. (A) Nitrite content was measured by Griess reaction and (B) $\mathrm{PGE}_{2}$ concentration was measured in the culture medium using a commercial enzyme-linked immunosorbent assay (ELISA) kit. Each value indicates the mean \pm standard deviation of results obtained from three independent experiments. ${ }^{*} \mathrm{P}<0.05$ indicates a significant difference from the value obtained for cells treated with LPS in the absence of EECO.

and ELISA, respectively. LPS triggered an approximate 7-fold increase in NO production compared with that in the untreated control group; however, pre-treatment with EECO reduced LPS-induced NO production in a concentration-dependent manner (Fig. 1A). The amount of $\mathrm{PGE}_{2}$ present in the culture medium also increased after $24 \mathrm{~h}$ of exposure to LPS alone; however, a concentration-dependent decrease was observed following pre-treatment with EECO (Fig. 1B).

Inhibition of LPS-induced $\mathrm{NO}$ and $\mathrm{PGE}_{2}$ expression by EECO. We then investigated whether the inhibitory effects of EECO on $\mathrm{NO}$ and $\mathrm{PGE}_{2}$ production are associated with decreased levels of iNOS and COX-2 expression, which are known to induce $\mathrm{NO}$ and $\mathrm{PGE}_{2}$ production, using western blot analysis and RT-PCR. The mRNA levels of iNOS and COX-2 were markedly augmented in the presence of LPS alone; however, their expression levels were markedly upregulated in the presence of EECO (Fig. 2A). Western blot analyses also revealed that treatment with LPS increased iNOS and COX-2 protein expression, whereas pre-treatment of the cells with EECO attenuated the LPS-induced iNOS and COX-2 protein expression (Fig. 3B). These results indicate that EECO inhibits the LPS-induced release of $\mathrm{NO}$ and $\mathrm{PGE}_{2}$ by suppressing iNOS and COX-2 expression at the transcriptional level. 


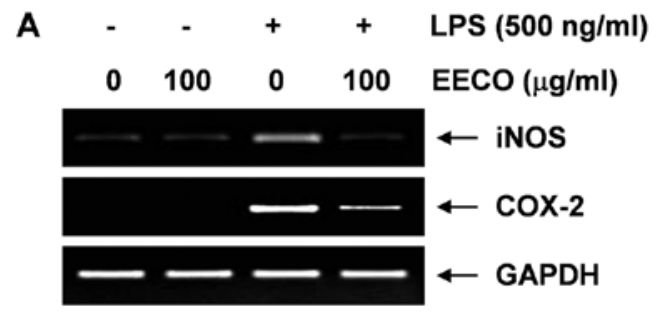

B

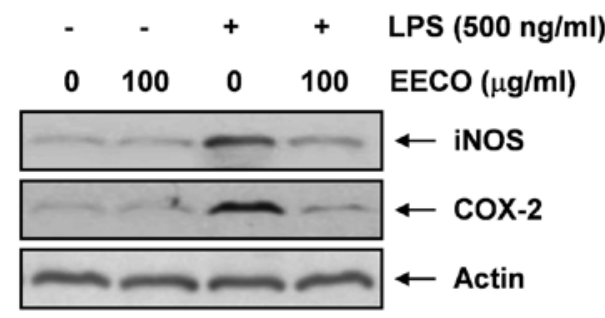

Figure 2. Inhibition of inducible nitric oxide (NO) synthase (iNOS) and cyclooxygenase-2 (COX-2) expression by the ethanol extract of Cnidium officinale rhizomes (EECO) in lipopolysaccharide (LPS)-stimulated BV2 microglial cells. (A) BV2 cells were treated with $100 \mu \mathrm{g} / \mathrm{ml} \mathrm{EECO} \mathrm{or} 500 \mathrm{ng} /$ $\mathrm{ml}$ LPS alone, or pre-treated with $100 \mu \mathrm{g} / \mathrm{ml}$ EECO for $1 \mathrm{~h}$ prior to treatment with LPS. Following treatment with LPS for $6 \mathrm{~h}$, total RNA was prepared for RT-PCR analysis of iNOS and COX-2 mRNA expression in LPS-stimulated BV2 microglial cells. (B) Cells were pre-treated with EECO $1 \mathrm{~h}$ prior to incubation with LPS $(500 \mathrm{ng} / \mathrm{ml})$ for $24 \mathrm{~h}$. The cells were then lysed and the same amounts of cellular proteins were separated on SDS-polyacrylamide gels. After the proteins were transferred onto nitrocellulose membranes, the membranes were probed with anti-iNOS and anti-COX-2 antibodies. The proteins were visualized using an ECL detection system. GAPDH and actin were used as internal controls for the RT-PCR and western blot assays, respectively.

Inhibition of LPS-induced TNF- $\alpha$ and IL-1 $\beta$ generation by $E E C O$. We then determined the potential effects of EECO on the production of pro-inflammatory cytokines, such as TNF- $\alpha$ and IL-1 $\beta$ by ELISA. The levels of TNF- $\alpha$ significantly increased in the culture medium of LPS-stimulated BV2 cells; however, the levels decreased significantly in a dose-dependent manner following pre-treatment with EECO (Fig. 3A). IL-1 $\beta$ production increased following stimulation with LPS and EECO significantly decreased the levels of IL- $1 \beta$ in the supernatant of LPS-stimulated BV2 cells (Fig. 3B).

Inhibition of LPS-induced TNF- $\alpha$ and IL-1 $\beta$ expression by EECO. RT-PCR and western blot analysis were performed in parallel experiments to determine whether EECO inhibits TNF- $\alpha$ and IL- $1 \beta$ expression. The increased expression of TNF- $\alpha$ and IL-1 $\beta$ following treatment with LPS was markedly attenuated by pre-treatment with EECO at both the transcriptional and translational levels (Fig. 4). These results indicate that EECO is effective in suppressing pro-inflammatory cytokine production by altering the transcriptional levels of TNF- $\alpha$ and IL- $1 \beta$ in LPS-activated microglia.

Inhibition of LPS-induced NF- $\kappa B$ translocation by EECO. As $\mathrm{NF}-\kappa \mathrm{B}$ is a central transcription factor that regulates the expression of a large number of inflammation-related genes $(7,26)$, the effects of EECO on the LPS-stimulated nuclear translocation of NF- $\kappa B$ p 65 subunits were examined. The western blot analysis results in Fig. 5A indicate that the levels of NF- $\mathrm{BB}$ p65 in the nucleus markedly increased within $15 \mathrm{~min}$ of exposure to LPS;
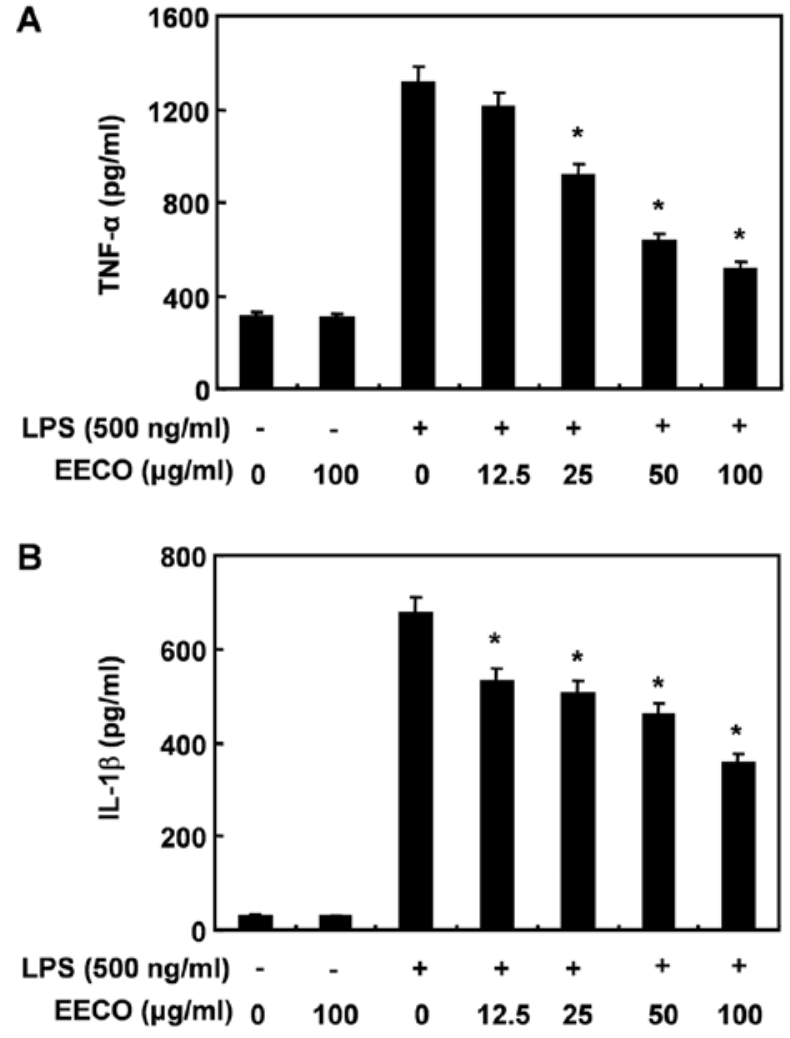

Figure 3. Effect of the ethanol extract of Cnidium officinale rhizomes (EECO) on lipopolysaccharide (LPS)-stimulated tumor necrosis factor- $\alpha$ (TNF- $\alpha$ ) and interleukin (IL)-1 $\beta$ production in BV2 microglia cells. BV2 cells were pre-treated with various concentrations of EECO for $1 \mathrm{~h}$ prior to treatment with $500 \mathrm{ng} / \mathrm{ml}$ LPS. After $2 \mathrm{~h}$ of incubation, the levels of (A) TNF- $\alpha$ and (B) IL-1 $\beta$ present in the supernatants were measured using enzyme-linked immunosorbent assay (ELISA). Each value indicates the mean \pm standard deviation of results obtained from three independent experiments. ${ }^{*} \mathrm{P}<0.05$ indicates a significant difference from the value obtained for the cells treated with LPS in the absence of EECO.

however, the LPS-induced p65 levels in the nuclear fraction decreased following pre-treatment with EECO. In addition, IкB- $\alpha$ was markedly degraded 15 min following exposure to LPS; however, the LPS-induced IкB- $\alpha$ degradation was significantly reversed by EECO. We also investigated whether EECO interferes with the translocation of NF- $\mathrm{KB}$ in LPS-treated BV2 cells by immunofluorescence. The level of NF- $\kappa B$ p 65 in the nucleus decreased significantly by EECO, indicating that EECO inhibits NF- $\mathrm{KB}$ activation in BV2 microglial cells by suppressing I $\kappa \mathrm{B}$ degradation and the nuclear translocation of NF- $\kappa B$ (Fig. 4B).

Inhibition of LPS-induced PI3K/Akt activation by EECO. As the activation of the PI3K/Akt signaling pathway leads to the production of inflammatory mediators and cytokines through the activation of NF- $\mathrm{KB}$ (9-12), we investigated the effects of EECO on the phosphorylation of PI3K and Akt proteins in LPS-stimulated BV2 cells. Using western blot analysis with anti-phospho-specific antibodies for PI3K and Akt, we found that EECO suppressed the LPS-induced phosphorylation of PI3K and Akt (Fig. 6), whereas the levels of non-phosphorylated PI3K and Akt were unaffected by either EECO or LPS treatment. These findings strongly suggest that the anti- 
A

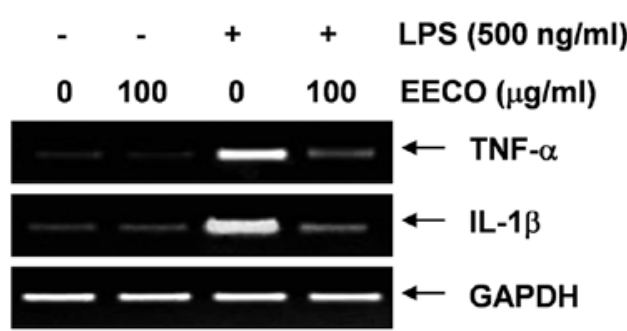

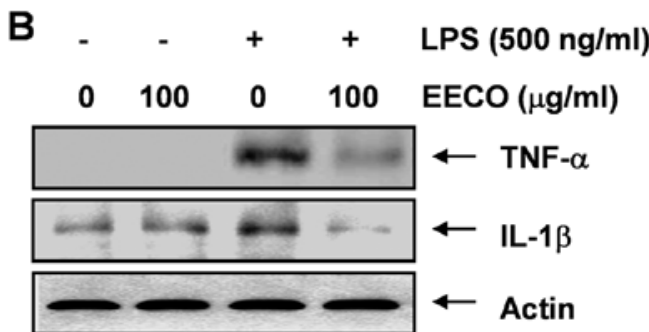

Figure 4. Inhibition of tumor necrosis factor- $\alpha$ (TNF- $\alpha$ ) and interleukin (IL)-1 $\beta$ expression by ethanol extract of Cnidium officinale rhizomes (EECO) in lipopolysaccharide (LPS)-stimulated BV2 microglia cells. (A) BV2 cells were treated with $100 \mu \mathrm{g} / \mathrm{ml} \mathrm{EECO} \mathrm{or} 500 \mathrm{ng} / \mathrm{ml} \mathrm{LPS} \mathrm{alone,} \mathrm{or} \mathrm{pre-treated} \mathrm{with} 100 \mu \mathrm{g} / \mathrm{ml}$ EECO for $1 \mathrm{~h}$ prior to treatment with LPS. Following treatment with LPS for $6 \mathrm{~h}$, total RNA was prepared for RT-PCR analysis of TNF- $\alpha$ and IL-1 $\beta$ mRNA expression in LPS-stimulated BV2 microglial cells. (B) Cells were pre-treated with EECO $1 \mathrm{~h}$ prior to incubation with LPS (500 $\mathrm{ng} / \mathrm{ml})$ for $24 \mathrm{~h}$. The cells were then lysed and the same amounts of cellular proteins were separated on SDS-polyacrylamide gels. After the proteins were transferred onto nitrocellulose membranes, the membranes were probed with anti-TNF- $\alpha$ and anti-IL-1 $\beta$ antibodies. The proteins were visualized using an ECL detection system. GAPDH and actin were used as internal controls for the RT-PCR and western blot assays, respectively.

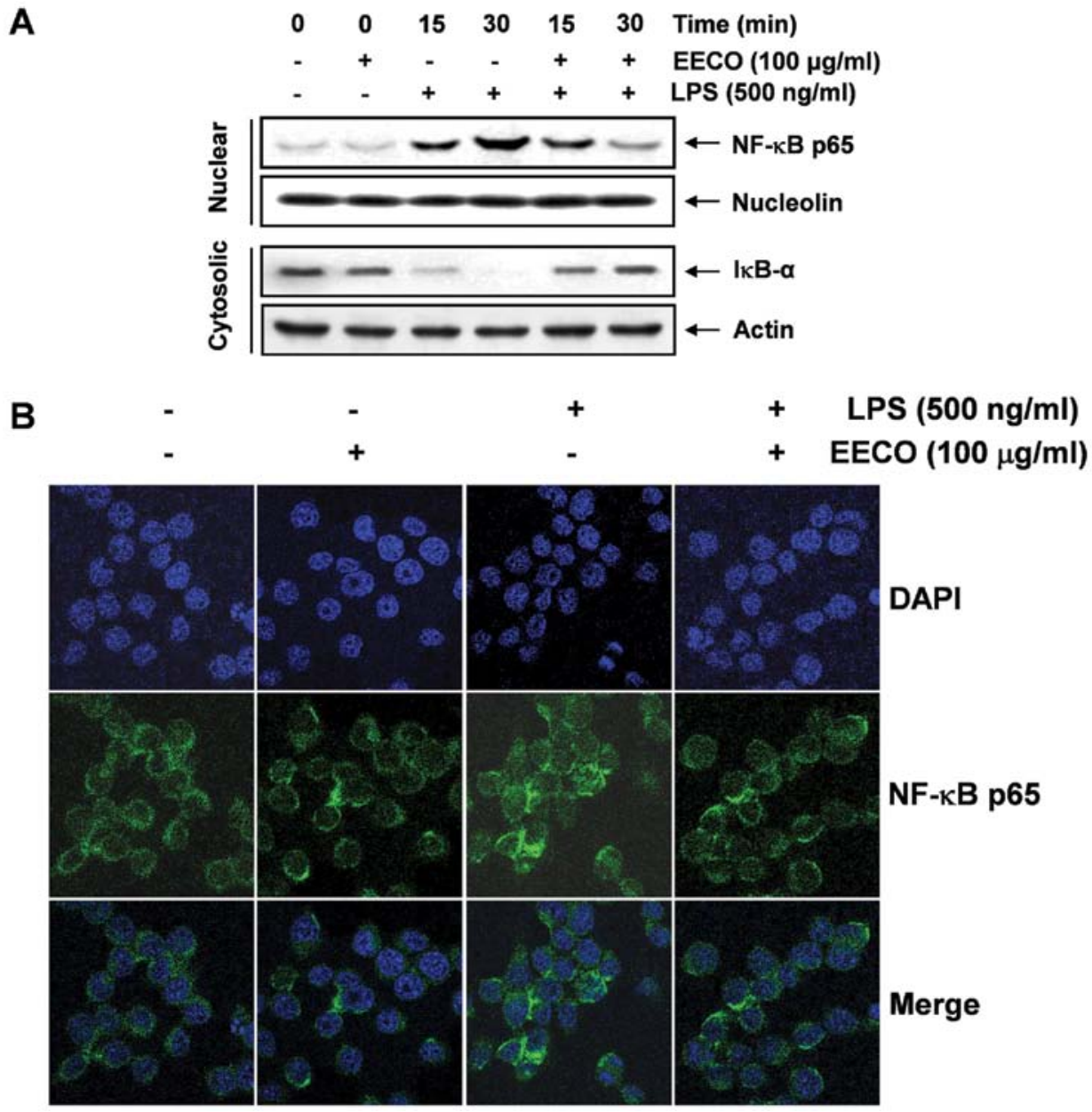

Figure 5. Effects of the ethanol extract of Cnidium officinale rhizomes (EECO) on lipopolysaccharide (LPS)-induced nuclear factor- $\mathrm{\kappa B}$ (NF- $\mathrm{\kappa B}$ ) translocation in BV2 microglial cells. (A) Cells were treated with $100 \mu \mathrm{g} / \mathrm{ml} \mathrm{EECO} \mathrm{for} 1 \mathrm{~h}$ prior to treatment with $500 \mathrm{ng} / \mathrm{ml}$ LPS for the indicated time periods of time. Nuclear and cytosolic proteins were isolated and subjected to $10 \%$ SDS-polyacrylamide gel electrophoresis followed by western blot analysis using antiNF-кB p65 and anti-IкB- $\alpha$ antibodies. Nucleolin was used as the internal control for the nuclear fraction. (B) BV2 cells were pre-treated with EECO for $1 \mathrm{~h}$ prior to stimulation with LPS for $1 \mathrm{~h}$. NF-kB p65 protein localization was determined using an anti-NF- $\mathrm{kB}$ p65 antibody and an fluorescein isothiocyanate (FITC)-labeled anti-rabbit IgG antibody, and cells were visualized under a laser confocal scanning microscope.

inflammatory effects of EECO in LPS-stimulated BV2 cells are associated with the inactivation of the PI3K/Akt pathway.

Effect of EECO on the viability of BV2 microglial cells. We evaluated the viability of BV2 cells incubated with or without LPS in the absence or presence of EECO by MTT assay to determine the cytotoxic effects (if any) of EECO on BV2 microglia. The concentrations (12.5 to $100 \mu \mathrm{M} / \mathrm{ml})$ of EECO used to inhibit LPS-induced inflammatory responses did not affect cell viability, confirming that the anti-inflammatory effects of EECO in LPS-stimulated BV2 cells are not due to the cytotoxicity of EECO (Fig. 7). 


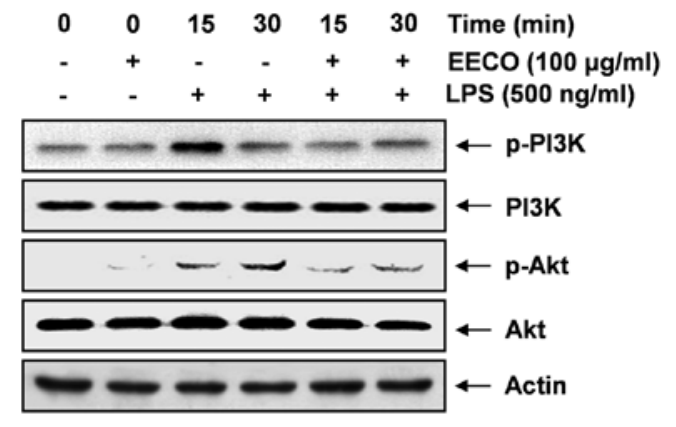

Figure 6. Effect of the ethanol extract of Cnidium officinale rhizomes (EECO) on lipopolysaccharide (LPS)-induced phosphorylation of phosphoinositide 3-kinase (PI3K) and Akt in BV2 microglial cells. BV2 cells were pre-treated with $100 \mu \mathrm{g} / \mathrm{ml}$ EECO for $1 \mathrm{~h}$ prior to treatment with LPS $(500 \mathrm{ng} / \mathrm{ml})$, and total proteins were isolated at the indicated times following treatment with LPS. Proteins were subjected to SDS-polyacrylamide gel electrophoresis followed by western blot analysis using the indicated antibodies, and an ECL detection system.

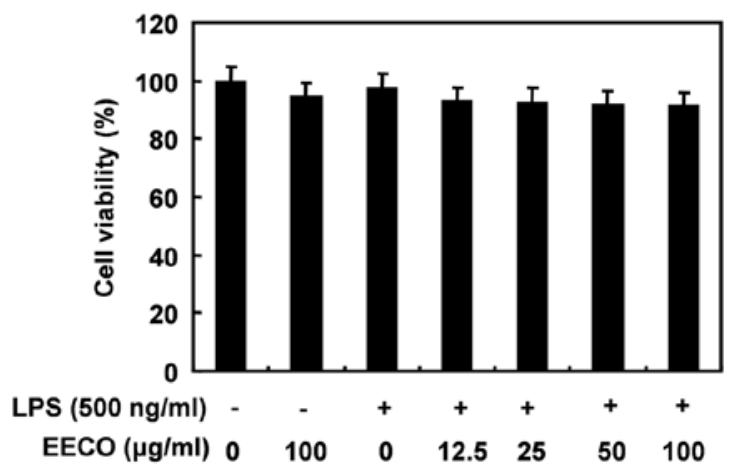

Figure 7. Effects of the ethanol extract of Cnidium officinale rhizomes (EECO) and lipopolysaccharide (LPS) on the viability of BV2 microglia cells. Cells were treated with $100 \mu \mathrm{g} / \mathrm{ml}$ EECO or $500 \mathrm{ng} / \mathrm{ml}$ LPS alone, or pretreated with the indicated concentrations of EECO for $1 \mathrm{~h}$ prior to treatment with LPS. After $24 \mathrm{~h}$, cell viability was assessed by MTT reduction assays. Each value indicates the mean \pm standard deviation of results obtained from three independent experiments.

\section{Discussion}

In the present study, we found that EECO impaired LPS-induced gene expression and the secretion of pro-inflammatory mediators ( $\mathrm{NO}$ and $\mathrm{PGE}_{2}$ ), as well as that of the inflammation-related genes, iNOS and COX-2, and cytokines (IL-1 $\beta$ and TNF- $\alpha$ ) in a BV2 microglia cell model. Further experiments revealed that EECO attenuated the LPS-induced NF- $\mathrm{KB}$ activation by suppressing the degradation of IкB- $\alpha$, which was associated with the inactivation of the PI3K/Akt signaling pathway.

Inflammation in the brain caused by activated microglia plays an important role in the pathology of neurodegenerative disorders $(5,6)$. iNOS and COX-2, which are responsible for synthesizing $\mathrm{NO}$ and $\mathrm{PGE}_{2}$, respectively, are critical enzymes that mediate inflammatory processes. The improper upregulation of iNOS and COX-2 has been associated with certain types of inflammatory disorders, including neuronal degeneration $(27,28)$. Pro-inflammatory cytokines also play critical roles in the process of inflammation and the increased production of these cytokines is associated with neuronal dysfunction and neuronal loss $(29,30)$. Therefore, the suppression of neuroinflammation during microglial activation would theoretically attenuate the progression of neurodegenerative disease. Thus, the inhibition of pro-inflammatory mediators and cytokines by EECO in LPS-stimulated BV2 microglia shown in the present study, may play a beneficial role in the treatment of neurodegenerative diseases.

$\mathrm{NF}-\mathrm{\kappa B}$ is an important transcription factor that regulates various cellular responses required for inducing the expression of inflammation-related genes $(7,26)$. In an inactive state, NF- $\kappa B$ exists as a heterodimer of p65 and p50 subunits in the cytoplasm, but translocates to the nucleus once activated through the phosphorylation and degradation of $\mathrm{I} \kappa \mathrm{B}$, and proceeds to transcribe the majority of pro-inflammatory genes, thus contributing to the development of anaphylaxis, septic shock, multiple organ failure and even cell death (31-33). In our experiments, the majority of intracellular NF- $\mathrm{kB}$ p65 had translocated from the cytosol to the nucleus following treatment with LPS, as demonstrated by strong NF- $\kappa B$ p65 accumulation and staining in the nucleus. However, the levels of NF- $\mathrm{BB}$ p 65 in the nucleus decreased significantly following pre-treatment with EECO. These results suggest that EECO inhibits LPS-induced acute pro-inflammatory responses mediated by the NF- $\mathrm{kB}$ signaling pathway.

The PI3K/AKT signaling pathway also controls a variety of cellular proliferation and survival processes. Upon stimulation, PI3K phosphorylates specific phosphoinositide lipids, which accumulate in the plasma membrane, creating docking sites for Akt. Akt undergoes phosphorylation at the plasma membrane, leading to its activation $(34,35)$. Numerous studies have shown that the PI3K/Akt signaling pathway plays an important role in negatively regulating LPS-induced acute inflammatory responses in microglia $(13,14,36-38)$. Although the role of PI3K/Akt signaling cascades in the regulation of $\mathrm{NF}-\mathrm{\kappa B}$ transactivation remains controversial $(8,39,40)$, certain studies have demonstrated that LPS-induced NF- $\mathrm{kB}$ activation is directly regulated as a main upstream molecule of NF- $\mathrm{KB}$ via the phosphorylation of Akt $(41,42)$. Therefore, to further confirm the inhibitory effects of NF- $\mathrm{\kappa B}$ activation by EECO, we investigated the effects of EECO on the levels of PI3K and Akt phosphorylation in LPS-stimulated BV2 cells. As a result, we found that PI3K and Akt phosphorylation was markedly suppressed by EECO. These results suggest that EECO inhibits LPS-induced NF- $\mathrm{KB}$ activation by inhibiting the activation of the PI3K/Akt pathway.

In conclusion, in this study, we demonstrate that EECO inhibits pro-inflammatory mediator and cytokine production by suppressing the activation of NF- $\mathrm{KB}$ in LPS-stimulated BV2 microglial cells. The regulation of NF- $\mathrm{KB}$ activity by EECO was also associated with the inactivation of the PI3K/Akt signaling pathway during the LPS-induced anti-inflammatory reaction. Therefore, the present results provide a molecular basis for understanding the inhibitory effects of $C$. officinale rhizomes on endotoxin-mediated inflammation.

\section{Acknowledgements}

This study was supported by the Basic Science Research Program through the National Research Foundation of Korea (NRF) grant funded by the Korean government (no. 2012046358) and the R\&D program of MKE/KEIT (10040391, Development of Functional Food Materials and Device for Prevention of Agingassociated Muscle Function Decrease). 


\section{References}

1. Hailer NP: Immunosuppression after traumatic or ischemic CNS damage: it is neuroprotective and illuminates the role of microglial cells. Prog Neurobiol 84: 211-233, 2008.

2. Kriz J: Inflammation in ischemic brain injury: timing is important. Crit Rev Neurobiol 18: 145-157, 2006.

3. Mirshafiey A and Jadidi-Niaragh F: Prostaglandins in pathogenesis and treatment of multiple sclerosis. Immunopharmaco Immunotoxicol 32: 543-554, 2010.

4. Dheen ST, Kaur C and Ling EA: Microglial activation and its implications in the brain diseases. Curr Med Chem 14: 1189-1197, 2007.

5. McGeer PL and McGeer EG: Inflammation, autotoxicity and Alzheimer disease. Neurobiol Aging 22: 799-809, 2001.

6. Liu B, Gao HM and Hong JS: Parkinson's disease and exposure to infectious agents and pesticides and the occurrence of brain injuries: role of neuroinflammation. Environ Health Perspect 111: 1065-1073, 2003.

7. Atreya I, Atreya R and Neurath MF: NF-kappaB in inflammatory bowel disease. J Intern Med 263: 591-596, 2008.

8. Tas SW, Vervoordeldonk MJ and Tak PP: Gene therapy targeting nuclear factor-kappaB: towards clinical application in inflammatory diseases and cancer. Curr Gene Ther 9: 160-170, 2009.

9. Qi S, Xin Y, Guo Y, Diao Y, Kou X, Luo L and Yin Z: Ampelopsin reduces endotoxic inflammation via repressing ROS-mediated activation of $\mathrm{PI} 3 \mathrm{~K} / \mathrm{Akt} / \mathrm{NF}-\kappa \mathrm{B}$ signaling pathways. Int Immunopharmacol 12: 278-287, 2012.

10. Kang CH, Jayasooriya RG, Dilshara MG, Choi YH, Jeong YK, Kim ND and Kim GY: Caffeine suppresses lipopolysaccharidestimulated BV2 microglial cells by suppressing Akt-mediated NF- $\kappa \mathrm{B}$ activation and ERK phosphorylation. Food Chem Toxicol 50: 4270-4276, 2012.

11. Yasuda T: Hyaluronan inhibits Akt, leading to nuclear factor- $\kappa \mathrm{B}$ down-regulation in lipopolysaccharide-stimulated U937 macrophages. J Pharmacol Sci 115: 509-515, 2011.

12. Chiou WF, Don MJ, Liao JF and Wei BL: Psoralidin inhibits LPS-induced iNOS expression via repressing Syk-mediated activation of PI3K-IKK-IкB signaling pathways. Eur J Pharmacol 650: 102-109, 2011.

13. Lee HS, Kwon SH, Ham JE, Lee JY, Kim DH, Shin KH and Choi SH: Zaprinast activates MAPKs, NFKB, and Akt and induces the expressions of inflammatory genes in microglia. Int Immunopharmacol 13: 232-241, 2012.

14. Lee YH, Jeon SH, Kim SH, Kim C, Lee SJ, Koh D, Lim Y, Ha K and Shin SY: A new synthetic chalcone derivative, 2-hydroxy3',5,5'-trimethoxychalcone (DK-139), suppresses the Toll-like receptor 4-mediated inflammatory response through inhibition of the Akt/NF- $\mathrm{B}$ pathway in BV2 microglial cells. Exp Mol Med 44: 369-377, 2012.

15. Bae KE, Choi YW, Kim ST and Kim YK: Components of rhizome extract of Cnidium officinale Makino and their in vitro biological effects. Molecules 16: 8833-8847, 2011.

16. de Caires S and Steenkamp V: Use of Yokukansan (TJ-54) in the treatment of neurological disorders: a review. Phytother Res 24: 1265-1270, 2010.

17. Bark KM, Heo EP, Han KD, Kim MB, Lee ST, Gil EM and Kim TH: Evaluation of the phototoxic potential of plants used in oriental medicine. J Ethnopharmacol 127: 11-18, 2010.

18. Jeong SI, Kwak DH, Lee S, Choo YK, Woo WH, Keum KS, Choi BK and Jung KY: Inhibitory effects of Cnidium officinale Makino and Tabanus fulvus Meigan on the high glucose-induced proliferation of glomerular mesangial cells. Phytomedicine 12: 648-655, 2005.

19. Kwon JH and Ahn YJ: Acaricidal activity of butylidenephthalide identified in Cnidium officinale rhizome against Dermatophagoides farinae and Dermatophagoides pteronyssinus (Acari: Pyroglyphidae). J Agric Food Chem 50: 4479-4483, 2002.

20. Tomoda M, Ohara N, Shimizu N and Gonda R: Characterization of a novel heteroglucan from the rhizome of Cnidium officinale exhibiting high reticuloendothelial system-potentiating and anticomplementary activities. Biol Pharm Bull 17: 973-976, 1994.

21. Jeong JB, Ju SY, Park JH, Lee JR, Yun KW, Kwon ST, Lim JH, Chung GY and Jeong HJ: Antioxidant activity in essential oils of Cnidium officinale Makino and Ligusticum chuanxiong Hort and their inhibitory effects on DNA damage and apoptosis induced by ultraviolet B in mammalian cell. Cancer Epidemiol 33: 41-46, 2009.
22. Jeong JB, Park JH, Lee HK, Ju SY, Hong SC, Lee JR, Chung GY, Lim JH and Jeong HJ: Protective effect of the extracts from Cnidium officinale against oxidative damage induced by hydrogen peroxide via antioxidant effect. Food Chem Toxicol 47: 525-529, 2009.

23. Kim SJ, Kwon do Y, Kim YS and Kim YC: Peroxyl radical scavenging capacity of extracts and isolated components from selected medicinal plants. Arch Pharm Res 33: 867-873, 2010.

24. Ramalingam M and Yong-Ki P: Free radical scavenging activities of Cnidium officinale Makino and Ligusticum chuanxiong Hort. methanolic extracts. Pharmacogn Mag 6: 323-330, 2010.

25. Bae DS, Kim YH, Pan CH, Nho CW, Samdan J, Yansan J and Lee JK: Protopine reduces the inflammatory activity of lipopolysaccharide-stimulated murine macrophages. BMB Rep 5: 108-113, 2012.

26. Tas SW, Remans PH, Reedquist KA and Tak PP: Signal transduction pathways and transcription factors as therapeutic targets in inflammatory disease: towards innovative antirheumatic therapy. Curr Pharm Des 11: 581-611, 2005

27. Shie FS, Montine KS, Breyer RM and Montine TJ: Microglial EP2 is critical to neurotoxicity from activated cerebral innate immunity. Glia 52: 70-77, 2005.

28. Aid S, Langenbach R and Bosetti F: Neuroinflammatory response to lipopolysaccharide is exacerbated in mice genetically deficient in cyclooxygenase-2. J Neuroinflammation 5: 17, 2008.

29. Leone S, Ottani A and Bertolini A: Dual acting anti-inflammatory drugs. Curr Top Med Chem 7: 265-275, 2007.

30. Mariani MM and Kielian T: Microglia in infectious diseases of the central nervous system. J Neuroimmune Pharmacol 4: 448-461, 2009.

31. Murphy K, Haudek SB, Thompson M and Giroir BP: Molecular biology of septic shock. New Horiz 6: 181-193, 1998.

32. Pushparaj PN, Tay HK, H'ng SC, Pitman N, Xu D, McKenzie A, Liew FY and Melendez AJ: The cytokine interleukin-33 mediates anaphylactic shock. Proc Natl Acad Sci USA 106: 9773-9778, 2009.

33. Manukyan MC, Weil BR, Wang Y, Abarbanell AM, Herrmann JL, Poynter JA and Meldrum DR: The phosphoinositide-3 kinase survival signaling mechanism in sepsis. Shock 34: 442-449, 2010.

34. Carnero A, Blanco-Aparicio C, Renner O, Link W and Leal JF: The PTEN/PI3K/AKT signalling pathway in cancer, therapeutic implications. Curr Cancer Drug Targets 8: 187-198, 2008.

35. Ito K, Caramori G and Adcock IM: Therapeutic potential of phosphatidylinositol 3-kinase inhibitors in inflammatory respiratory disease. J Pharmacol Exp Ther 321: 1-8, 2007.

36. Choi YH and Park HY: Anti-inflammatory effects of spermidine in lipopolysaccharide-stimulated BV2 microglial cells. J Biomed Sci 19: 31, 2012.

37. Park HY, Han MH, Kim GY, Kim ND, Nam TJ and Choi YH: Inhibitory effects of glycoprotein isolated from Laminaria japonica on lipopolysaccharide-induced pro-inflammatory mediators in BV2 microglial cells. J Food Sci 76: T156-T162, 2011.

38. Park HY, Kim GY and Choi YH: Naringenin attenuates the release of pro-inflammatory mediators from lipopolysaccharidestimulated BV2 microglia by inactivating nuclear factor- $\kappa \mathrm{B}$ and inhibiting mitogen-activated protein kinases. Int J Mol Med 30: 204-210, 2012

39. Takeshima E, Tomimori K, Kawakami H, Ishikawa C, Sawada S, Tomita M, Senba M, Kinjo F, Mimuro H, Sasakawa C, Fujita J and Mori N: NF-kappaB activation by Helicobacter pylori requires Akt-mediated phosphorylation of p65. BMC Microbiol 9: 36, 2009.

40. Wei J and Feng J: Signaling pathways associated with inflammatory bowel disease. Recent Pat Inflamm Allergy Drug Discov 4: 105-117, 2010.

41. Dan HC, Cooper MJ, Cogswell PC, Duncan JA, Ting JP and Baldwin AS: Akt-dependent regulation of NF-kappaB is controlled by mTOR and Raptor in association with IKK. Genes Dev 22: 1490-1500, 2008.

42. Minhajuddin M, Bijli KM, Fazal F, Sassano A, Nakayama KI, Hay N, Platanias LC and Rahman A: Protein kinase C-delta and phosphatidylinositol 3-kinase/Akt activate mammalian target of rapamycin to modulate NF-kappaB activation and intercellular adhesion molecule-1 (ICAM-1) expression in endothelial cells. J Biol Chem 284: 4052-4061, 2009. 